\title{
Jeffrey H. Haeni Named 2002-2003 OSA/MRS Fellow, Will Work with Rep. Rush Holt
}

Jeffrey H. Haeni has been named the 2002-2003 OSA/MRS Congressional Science and Engineering Fellow. His tenure began in September. As a recipient of this one-year appointment, sponsored jointly by the Optical Society of America and the Materials Research Society, Haeni will work in the office of Rep. Rush Holt (D-N.J.) as a consultant on scientific and technical matters.

"I believe it is important for scientists to take an active role in the legislative process," Haeni said. "A quick glance at current issues-stem-cell research, energy policy, bio-terrorism, climate-change, missile defense, and the economic downturnreveals that the scientific community will not only be directly affected by legislative action on all of these matters, but will be instrumental in finding appropriate solutions."

He said that Holt is one of two "PhD physicists" on Capitol Hill. Among his committee assignments, Holt serves on the "21st Century Competitiveness" and "Select Education" subcommittees of the House Education and the Workforce committee.

Along with research conducted at The Pennsylvania State University, Haeni worked in research at the University of Augsburg in Germany and participated

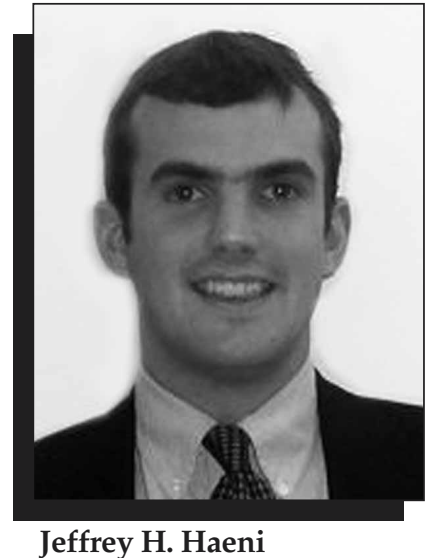

in a Habitat for Humanity project in New Zealand, where he assisted the Ngaitai Maori tribe in building homes.

"I gained valuable exposure to a different model of university education, alternative programs for social welfare, and a view of the influence that American domestic and international policies have on other countries," said Haeni. He said that these experiences will help him consider the goals and perspectives of each stakeholder for any given issue, which he believes is important to the effectiveness of legislation.
Howard Schlossberg of OSA, who chaired the 2002-2003 Fellow selection committee, said, "Jeff's ability to speak passionately about his beliefs and translate his knowledge to a wide range of audiences, technical and nontechnical, should make him an excellent representative for the science and engineering community in Washington."

Michal Freedhoff, chair of the MRS Congressional Fellow Subcommittee, said, "Jeff brings a unique mix to Capitol Hill-rigorous scientific training and a demonstrated and longstanding commitment to trying to make the world a better place. I'm sure he will make many valuable contributions during his year in Congressman Holt's office."

Haeni received his $\mathrm{PhD}$ degree in materials science in August 2002 from Penn State. His research interests involve the investigation and growth of high-к epitaxial gate dielectrics and other perovskite materials on silicon. He has held several fellowships and has most recently been named Semiconductor Research Corporation Graduate Fellow (2001-2003). He has published three lead-author articles in refereed journals and was an invited coauthor of an article in the March 2002 issue of MRS Bulletin.

\section{E-Mail Alerts and Discussion Groups}

Sign up for any of these FREE services today* and let the Materials Research Society bring materials information to you!

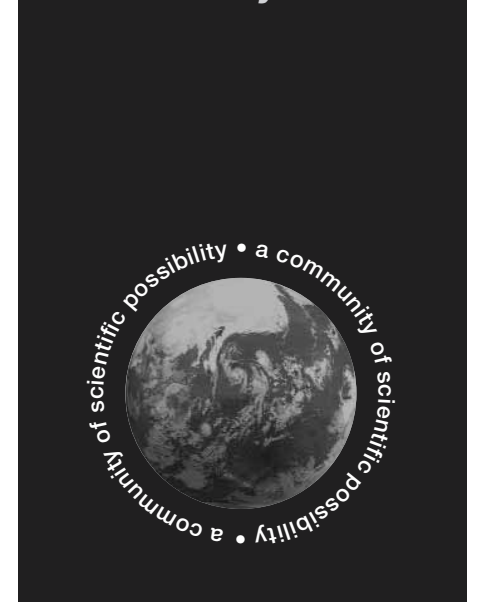

Just Published! Alert mrs-justpublished-subscribe@mrs.org
MRS announces a new service for both its members and the materials research community_Just Published! Alert. This FREE listserv will provide notice of new proceedings volumes and other publications from the Materials Research Society, as they are published. Sign up today and find out what's new and available, as soon as it's available.

\section{Publications Alert}

mrs-pubs-alert-subscribe@mrs.org

Publications Alert provides advance table-of-contents listings for the MRS Bulletin and Journal of Materials Research. Subscribers receive each alert prior to the availability of the print version.

\section{MRS E-News}

mrs-enews-subscribe@mrs.org

Receive a monthly e-newsletter on the latest new research highlights, professional opportunities or other materials information. Subscribe to MRS E-News today.

\section{MRS Public Affairs Alert}

\section{mrs-publicaffairs-subscribe@mrs.org}

MRS Public Affairs Alert provides occasional summaries of current public-policy issues affecting the materials science and engineering community. Learn how you can make a difference.

\section{Women in MS\&E}

\section{mrs-women-subscribe@mrs.org}

Join a mailing list for a continuing discussion and information exchange on issues affecting women in the materials profession. Women and men are both welcome to participate.

* To subscribe, e-mail the appropriate address above and include the word "subscribe" in the subject line. 